\title{
POTENSI DAERAH RAWAN TANAH LONGSOR DI KECAMATAN PATUK, YOGYAKARTA MENGGUNAKAN SISTEM INFORMASI GEOGRAFI (SIG)
}

\author{
${ }^{(1)}$ Reni Aqwil Masithah ${ }^{(2)}$ Dra. Hj. Lily Handayani, M.Si ${ }^{(2)}$ Ir. Warsiyah, M.Sc \\ ${ }^{(1)}$ Mahasiswa Jurusan Teknik Lingkungan Institut Teknologi Yogyakarta \\ (STTL"YLH) \\ ${ }^{(2)}$ Dosen Jurusan Teknik Lingkungan Institut Teknologi Yogyakarta (STTL”YLH) \\ Jalan Janti Km. 04 Gedongkuning Yogyakarta \\ Email: reniaqwilmasithah@gmail.com
}

\begin{abstract}
INTISARI
Kecamatan Patuk termasuk salah satu Sub Zona Fisiografi Pegunungan Baturagung bersama Kecamatan Gedangsari, Ngawen dan Semin. Wilayah tersebut didominasi perbukitan-pergunungan, dengan ketinggian berkisar $200-700 \mathrm{~m}$ dan kelerengan berkisar 8 - >40\%. Di daerah Patuk ini juga terdapat formasi Geologi Nglanggeran, Wonosari, Sambipitu, Semilir, dan Nampol, sedangkan untuk jenis tanahnya mayoritas terdiri dari litosol, regosol dan grumusol yang relatif peka terhadap longsor. Curah hujan yang tinggi berkisar 2000-2500 mm/tahun membuat Kecamatan Patuk rawan terhadap terjadinya bencana longsor. Dengan dilakukan penelitian ini, akan diketahui persebaran dari risiko rawan longsor di Kecamatan Patuk dan usaha mitigasi yang dapat dilakukan.

Pengumpulan data beberapa parameter melalui BAPPEDA tentang curah hujan, kondisi batuan, jenis tanah, penggunaan lahan dan kemiringan lereng. Selain itu juga dilakukan observasi secara langsung melalui fieldcheck. Data yang telah dikumpulkan lalu diolah melalui seperangkat komputer dengan software ArcGIS 10.3.Setelah dilakukan overlay dari kelima parameter maka didapatkan petadistribusi risiko bencana tanah longsor. Analisis data hasil penelitian berupa peta rawan bencana tanah longsor akan dilakukan secara deskriptif.

Wilayah dengan tingkat kerawanan tinggi terletak pada Desa Nglegi dengan luasan 5,94 km², Desa Terbah dengan luasan 4,96 km² dan Desa Ngoro oro dengan luasan $2,91 \mathrm{~km}^{2}$. Pada 3 desa tersebut diketahui memiliki kemiringanlereng tinggi yaitu lebih dari $45 \%$ dan curah hujan tinggi berkisar 2000-2500 mm/tahun. Jenis tanah Desa Nglegi berupa komplek regosol dan grumusol memiliki kepekaan terhadap longsor tinggi. Wilayah yang memiliki tingkat kerawanan rendah berada di Desa Bunder dengan luasan yaitu $5,29 \mathrm{~km}^{2}$, kemiringanlereng yang cukup landai dan banyaknya kebun di Desa Bunder membuatsebagian besar daerah desa tidak mudah mengalami bencana longsor. Wilayah dengan tingkat kerawanan sedang yang cukup luas terletak pada Desa Nglanggeran dengan luasan $6,31 \mathrm{~km}^{2}$, Desa Semoyo dengan luasan 5,70 $\mathrm{km}^{2}$ dan Desa Putat dengan luasan 5,21 $\mathrm{km}^{2}$. Tindakan mitigasi yang dapat dilakukan yaitu dengan papan peringatan rawan bencana tanah longsor, penggunaan webbing jute dan slope reshapping.
\end{abstract}

Kata kunci: Tanah longsor, Sistim Infromasi Geografis 


\title{
POTENTIAL AREAS PRONE TO LANDSLIDES IN DISTRICT PATUK, YOGYAKARTA USING THE GEOGRAPHIC INFORMATION SYSTEM (GIS
}

\begin{abstract}
Patuk Sub district was one of subzone of Baturagung Mt. together with Gedangsari Sub district, Ngawen and Semin. That area contained many hills and mountains with average height $200-700 \mathrm{~m}$ and the slope interval was $8->40 \%$. At Patuk Sub district could be found Nglanggaran Geology Formation, Wonosari, Sambipitu, Semilir, and Nampol, while the soil was mostly contained of grumusol, regosol and litosol type which relatively so sensitive with erosion. High rainfall rate in Patuk Sub district revolved at 2000-2500 mm/year. So the research done with purpose to know about the risk distribution of landslide in Patuk Sub district and how to prevent it.

First step of this research was to collect few parameter data by BAPPEDA about rainfall rate, geology condition, soil type, land use and slope data. In addition we did observation too directly to the location. The data that have been obtained, to process with GIS Software 10.3. After we did the overlay from five parameter, results of analysis showed risk distribution map of landslide in Patuk District. The result of this research will be a map which shows the dangerous area which vulnerable with landslide. Data analysis about the research result would do descriptively.

Highest risk located at Nglegi Village 5,94 $\mathrm{km}^{2}$, Terbah Village $4,96 \mathrm{~km}^{2}$ and Ngoro oro $2,91 \mathrm{~km}^{2}$. At those 3 villages can be found out that they have steep slope more than 45\% and high rainfall rate about 2000-2500 mm/year. The soil in Nglegi village was sensitive type to landslide which contain of regosol and grumusol soil. Lowest risk located at Bunder Village $5,29 \mathrm{~km}^{2}$ with land which relatively flat and many plantation at that village make this village not in danger condition. Middle risk located at nglanggeran Village $6,31 \mathrm{~km}^{2}$, Semoyo Village $5,70 \mathrm{~km}^{2}$ and Putat Village 5,21 $\mathrm{km}^{2}$. Prevention action that will do is to supply warning street sign about landslide risk, using webbing jute in several location and do slope reshaping.
\end{abstract}

Keywords:landslide, Geography Information System

\section{Pendahuluan}

Cuaca ekstrim akibat perubahan iklim global banyak mendatangkan bencana alam baik bencana banjir, longsor dan lain-lain. Contoh dari cuaca ekstrim tersebut antara lain Elnino, Lanina dan Dipole Mode. Cuaca ekstrim tersebut membuat Indonesia sangat rawan terjadi bencana alam karena Indonesia sendiri berada 
pada tiga lempeng tektonik aktif (Arsjad dan Riadi, 2013). Diantara bencana alam yang berpotensi mendatangkan bahaya bagi penduduk di suatu wilayah adalah tanah longsor atau land slide. Longsor merupakan proses geomorfologi dalam menuju keseimbangan baru permukaan bumi. Jika longsor terjadi dalam skala besar maka akan mendatangkan kerugian besar karena bersifat destruktif dan juga terkadang menelan korban jiwa (Arsjad, 2012).

Kabupaten Gunungkidul adalah salah satu propinsi yang terletak di Propinsi Daerah Istimewa Yogyakarta (DIY). Penelitian ini akan bertempat di Kecamatan Patuk yang termasuk salah satu Sub Zona Fisiografi Pegunungan Baturagung bersama Kecamatan Gedangsari, Ngawen dan Semin. Secara dominan wilayah tersebut berupa perbukitan-pergunungan, dengan ketinggian berkisar $200-700$ $\mathrm{m}$ dan kelerengan berkisar $8->40 \%$. Di daerah Patuk ini juga terdapat formasi Geologi Andesit, Gunungwungkal, Wuni, Semilir, Nglangran dan Mandalika, sedangkan untuk jenis tanahnya adalah jenis rensina (Badan Pusat Statistik Kabupaten Gunungkidul, 2013).

Terjadinya longsor bisa diketahui sebelumnya dengan cara salah satunya yaitu memetakan daerah yang diprediksi rawan tanah longsor sebagai alat bantu dan melakukan tindakan pencegahan. Dengan mengetahui status kawasan tersebut kita dapat melakukan upaya-upaya komprehensif untuk mengurangi resiko bencana tanah longsor, antara lain dengan melakukan kegiatan mitigasi yaitu upaya-upaya untuk meminimalkan dampak yang ditimbulkan oleh bencana dengan melakukan analisis terhadap kerawanan tanah longsor.

Mitigasi tanah longsor dilakukan dengan memperhatikan keberlangsungan kondisi tanah pada suatu lereng. Oleh karena itu, perlakuan khusus melalui upaya konservasi tanah menjadi suatu hal yang penting. Upaya konservasi tanah sangat membantu dalam menstabilkan tanah, terutama untuk membuat lereng stabil.

Untuk dapat memantau dan mengetahui potensi daerah-daerah yang memiliki potensi terjadinya tanah longsor, penelitian ini akan dibantu dengan software ArcGIS 10.3 yang akan dilakukan perhitungan skor kerawanan (kumulatif) sehingga didapatkan peta persebaran daerah rawan longsor. Dengan dihasilkannya peta persebaran daerah rawan longsor di Kecamatan Wonosari, maka hasil dari kajian peta tersebut dapat memberikan kita gambaran tentang upaya konservasi yang dapat dilakukan terhadap daerah tersebut. 


\section{Rumusan Masalah}

1. Bagaimana sebaran potensi tanah longsor di Kecamatan Patuk?

2. Apa saja faktor yang berpengaruh terhadap potensi terjadinya tanah longsor di Kecamatan Patuk?

3. Apa saja kegiatan konservasi yang dilakukan sebagai bentuk mitigasi terhadap bencana tanah longsor tersebut?

\section{Tujuan}

1. Mengetahui faktor-faktor yang berpengaruh terhadap terjadinya tanah longsor di Kecamatan Patuk.

2. Memetakan penyebaran kawasan rawan bencana tanah longsor di Kecamatan Patuk.

3. Mengetahui tindakan konservasi tanah yang harus diupayakan sebagai bentuk mitigasi bencana tanah longsor di Kecamatan Patuk.

\section{Manfaat}

1. Memberikan informasi yang termuat dalam bentuk peta mengenai daerah rawan tanah longsor.

2. Memberikan peringatan sedini mungkin terhadap kemungkinan terjadinya tanah longsor.

\section{Tinjauan Pustaka}

\section{Tanah Longsor}

Tanah longsor merupakan bencana alam yang sering terjadi di Indonesia dan menimbulkan dampak cukup besar secara material maupun non material. Tanah longsor dapat terjadi akibat faktor statis (kemiringan lereng) dan faktor dinamis (tata guna lahan). Beberapa daerah rawan longsor di Indonesia antara lain Jawa Barat, Jawa Tengah, Sumatra Barat, sebagain Lampung, Sulawesi Tengah, Sulawesi Selatan, Nusa Tenggara Timur dan sebagian Papua (Rendra dkk, 2016).

Tanah Longsor secara umum adalah perpindahan material pembentuk lereng berupa batuan, bahan rombakan, atau tanah yang bergerak ke bawah atau keluar lereng. Secara geologi tanah longsor adalah suatu peristiwa geologi dimana terjadi pergerakan tanah seperti jatuhnya bebatuan atau gumpalan besar tanah (Nandi, 2007).

\section{Penyebab Terjadinya Tanah Longsor}

Highland dan Bobrowsky (2008) menuliskan bahwa ada 2 penyebab primer dari tanah longsor yaitu : manusia dan alam. Bahkan terkadang tanah longsor disebabkan dari kombinasi keduanya yang membuat kejadian tanah longsor tersebut lebih buruk. Faktor alam utama yang dapat menyebabkan tanah longsor yaitu air, 
aktivitas seismik dan aktivitas gunung berapi. Efek dari ketiga penyebab tersebut sangatlah bervariasi dan tergantung dari faktornya, antara lain kemiringan lereng, morfologi atau bentuk dari sebuah medan, jenis tanah, dan ada atau tidaknya masyarakat disekitar area yang terkena efeknya.

Faktor Alam : Air

Kejenuhan air sebuah lereng merupakan penyebab utama terjadinya tanah longsor. Kejenuhan tersebut bisa muncul dalam bentuk turunnya hujan lebat, perubahan tingkat dalam air tanah, kenaikan level permukaan air sepanjang pantai, di danau, bendungan air, dan sungai (Highland dan Bobrowsky, 2008). Musim kering yang panjang akan menyebabkan terjadinya penguapan air di permukaan tanah dalam jumlah besar. Hal itu menyebabkan munculnya pori-pori atau rongga tanah hingga terjadi retakan dan merekahnya tanah permukaan. Ketika hujan, air akan menyusup ke bagian yang retak sehingga tanah dengan cepat mengembang kembali. Pada awal musim hujan, intensitas hujan yang tinggi biasanya sering terjadi, sehingga kandungan air pada tanah menjadi jenuh dalam waktu singkat. Hujan lebat pada awal musim dapat menimbulkan longsor karena melalui tanah yang merekah air akan masuk dan terakumulasi dibagian dasar lereng, sehingga menimbulkan gerakan lateral (Nandi, 2007).

Curah hujan yang turun akan mempengaruhi kondisi air tanah, tanah yang kandungan air tanahnya meningkat maka akan meningkat massanya dan semakin rendah tingkat kepadatan dan kekompakannya.

Longsoran disebabkan oleh kondisi tata air tanah dan sifat fisik/mekanik tanah yang tidak baik, sehingga pada saat musim hujan telah terjadi air tinggi sehingga dapat menimbulkan peningkatan tekanan air tanah (pore water pressure), penurunan kekuatan dan tahanan geser tanah akan menyebabkan longsoran (BBSDLP , 2009).

Faktor Alam : Aktivitas Seismik

Banyaknya daerah yang berbukit membuat daerah tersebut lebih mudah mengalami tanah longsor. Dan juga daerah yang sering mengalami gempa bumi. Terjadinya gempa bumi di daerah dataran yang cukup tinggi meningkatkan kemungkinan terjadinya tanah longsor di daerah tersebut (Highland dan Bobrowsky, 2008). Getaran yang yang terjadi biasanya diakibatkan oleh gempa bumi, ledakan, getaran mesin dan getaran lalu lintas kendaraan. Akibat yang ditimbulkannya adalah tanah, badan jalan, lantai, dan dinding rumah menjadi retak (Nandi, 2007). Munculnya retakan di permukaan 
bumi tersebut yang membuat infiltrasi air lebih mudah terjadi.

Faktor Alam : Aktivitas Gunung Berapi

Menurut Highland dan Bobrowsky (2008), tanah longsor yang disebabkan aktivitas gunung berapi merupakan tipe paling mengenaskan. Lava gunung berapi dapat melelehkan salju dengan cepat dan menyebabkan banjir lahar dingin yang akan turun dengan cepat dan menghabcurkan segala benda di depannya. Bangunanbangunan volkanik rata-rata masih muda, tidak solid dan secara geologis memiliki struktur yang lemah yang dapat runtuh kapan saja dan menyebabkan runtuhnya bebatuan dan tanah longsor.

\section{Faktor Manusia}

Meningkatnya populasi yang mengisi lahan baru dan membangun sebuah desa dan kota merupakan arti sebenarnya dari kontribusi manusia terhadap terjadinya tanah longsor. Mengganggu atau mengubah bentuk drainase alami, membuat ketidakstabilan sebuah lereng, dan menghilangkan vegetasi alami merupakan tindakan yang umum dilakukan oleh manusia yang akhirnya dapat menyebabkan terjadinya tanah longsor (Highland dan Bobrowsky, 2008).

Berdasarkan Paimin dkk (2009) pengalaman lapangan, proses tanah longsor bisa dipilah dalam tiga tingkatan yakni: massa tanah sebagian besar telah meluncur ke bawah (longsor), massa tanah bergeser sehingga menimbulkan rekahan/retak (rayapan), dan massa tanah belum bergerak tetapi memiliki potensi longsor tinggi (potensial longsor)

Beberapa hal yang perlu diperhatikan pada daerah longsor maupun rawan longsor adalah sebagai berikut:

1. Slope reshaping lereng terjal (pembentukan lereng lahan menjadi lebih landai) pada daerah yang potensial longsor.

2. Penguatan lereng terjal dengan bronjong kawat pada kaki lereng.

3. Penutupan rekahan/retakan tanah dengan segera karena pada musim penghujan rekahan bisa diisi oleh air hujan yang masuk ke dalam tanah sehingga menjenuhi tanah di atas lapisan kedap.

Bangunan rumah dari kontruksi kayu (semi permanen) lebih tahan terhadap retakan tanah disbanding dengan bangunan pasangan batu/bata pada lahan yang masih akan bergerak.

\section{Teknik Konservasi Vegetatif}

Rendra dkk (2009) menyatakan bahwa rekayasa vegetatif merupakan teknik penggunaan tumbuhan dan sisasisa tumbuhan untuk mengurangi daya rusak akibat hujan yang jatuh, mengurangi jumlah dan daya rusak aliran permukaan serta erosi. Teknik ini menjadi salah satu teknik 
pencegahan tanah longsor yang efektif dan efisien bagi kondisi lereng karena mampu memperbaiki kapasitas infiltrasi lereng dengan biaya yang relatif lebih murah dan menambah keindahan bentang alam.

Teknik pengendalian tanah longsor metode vegetatif (konservasi vegetatif) harus dipilahkan antara bagian kaki, bagian tengah, dan bagian atas lereng. Stabilisasi tanah diutamakan pada kaki lereng, baik dengan tanaman (vegetatif) maupun bangunan. Persyaratan vegetasi untuk pengendalian tanah longsor antara lain: jenis tanaman memiliki sifat perakaran dalam (mencapai batuan), perakaran rapat dan mengikat agregat tanah, dan bobot biomassanya ringan. Pada lahan yang rawan longsor, kerapatan tanaman beda antara bagian kaki lereng (paling rapat=standar kerapatan tanaman), tengah (agak jarang= $1 / 2$ standar) dan atas (jarang= $1 / 4$ standar). Kerapatan yang jarang diisi dengan tanaman rumput dan atau tanaman penutup tanah (cover crop) dengan drainase baik, seperti pola agroforestri. Pada bagian tengah dan atas lereng diupayakan perbaikan sistem drainase (internal dan eksternal) yang baik sehingga air yang masuk ke dalam tanah tidak terlalu besar, agar tingkat kejenuhan air pada yanah yang berada di atas lapisan kedap (bidang gelincir) bisa dikurangi bebannya (Paimin dkk, 2009).

\section{Teknik Konservasi Mekanik}

Konservasi tanah mekanik adalah semua perlakuan fisik mekanis yang diberikan kepada tanah dan pembuatan bangunan yang ditujukan untuk mengurangi aliran permukaan dan erosi serta meningkatkan kelas kemampuan tanah. Teknik konservasi tanah ini dikenal pula dengan sebutan metode teknis sipil.

Perlakuan fisik mekanis terhadap tanah tetap diperlukan meskipun metode sipil teknis bukan menjadi pilihan utama, namun perlakuan fisik mekanis seperti pembuatan saluran pembuangan air (SPA) atau bangunan terjunan masih tetap diperlukan untuk mengalirkan sisa aliran permukaan yang tidak terserap oleh tanah. Teknik konservasi mekanik juga perlu dipertimbangkan bila masalah erosi sangat serius dan atau teknik konservasi vegetatif dinilai sudah tidak efektif lagi untuk menanggulangi erosi yang terjadi. Pada prakteknya, sulit dipisahkan antara teknik konservasi mekanik dan teknik konservasi vegetatif. Penenerapan teknik konservasi tanah secara mekanik juga akan lebih efektif dan efisien apabila dikombinasikan dengan teknik konservasi tanah vegetatif, seperti penggunaan rumput atau legume sebagai tanaman penguat teras, penggunaan mulsa, ataupun pengaturan pola tanam. 
Selain terasering dan berbagai bentuk teras lainnya, misalnya teras gulud, teras kebun, teras kredit, dan teras individu, metode konservasi tanah lainnya yang tergolong sebagai tindakan mekanik adalah rorak,mulsa vertical, barisan batu, saluran drainase (saluran pengelak, saluran pembuangan air dan bangunan terjunan), pembuatan bedengan searah kontur, dan lain sebagainya. Olah tanah konservais (olah tanah minimum, tanpa olah tanah, pengolahan tanah menurut kontur) juga termasuk teknik konservasi mekanik (Dariah dkk, 2009).

\section{Sistem Informasi Geografis}

Tantangan besar yang sedang kita hadapi di seluruh dunia saat ini yaitu overpopulation, polusi, berkurangnya luas hutan dan bencanan alam. Semua permasalahan itu mempunyai dimensi secara geografis. Permasalahan lokal juga memiliki komponen geografis yang dapat divisualisasikan dengan menggunakan Sistem Informasi Geografis (SIG).

\section{Definisi SIG}

Beberapa definisi SIG menurut para ahli :

1. Menurut Aronoff, 1989.

SIG adalah sistem informasi yang didasarkan pada kerja komputer yang memasukkan, mengelola, memanipulasi dan menganalisa data serta memberi uraian.

2. Menurut Burrough, 1986.

SIG merupakan alat yang bermanfaat untuk pengumpulan, penimbunan, pengambilan kembali data yang diinginkan dan penayangan data keruangan yang berasal dari kenyataan dunia.

3. Menurut Marble et al, 1983.

SIG merupakan sistem penanganan data keruangan.

4. Menurut Berry, 1988.

SIG merupakan sistem informasi, referensi internal, serta otomatisasi data keruangan.

5. Menurut Calkin dan Tomlinson, 1984.

SIG merupakan sistem komputerisasi data yang penting.

Secara umum pengertian SIG yaitu suatu komponen yang terdiri dari perangkat keras, perangkat lunak, data geografis dan sumberdaya manusia yang bekerja bersama secara efektif untuk memasukan, menyimpan, memperbaiki, memperbaharui, mengelola, memanipulasi, mengintegrasikan dan menampilkan data dalam suatu informasi berbasis geografis ( Hartoyo dkk, 2010).

SIG mempunyai kemampuan untuk menghubungkan berbagai data pada suatu titik tertentu di bumi, menggabungkannya, menganalisa dan akhirnya memetakan hasilnya.data 
yang akan diolah padda SIG merupakan data spasial yaitu sebuah data yang berorientasi geografis dan merupakan lokasi yang memiliki sistem koordinat tertentu, sebagai dasar referensinya. Sehingga aplikasi SIG dapat menjawab beberapa pertanyaan seperti; lokasi, kondisi, trend, pola dan pemodelan. Kemampuan inilah yang membedakan SIG dari sistem informasi lainnya.

\section{Cara Kerja SIG}

SIG menyimpan semua informasi deskriptif unsur-unsurnya sebagai atribut-atribut basis data. Kemudian SIG membentuk dan menyimpannya dalam tabel-tabel. Setelah itu SIG menghubungkan unsur-unsur diatas dengan tabel-tabel bersangkutan. Dengan demikian atribut-atribut dapat diakses melalui lokasi-lokasi unsur-unsur peta dan sebaliknya unsur-unsur peta juga dapat diakses melalui atributnya. Karena itu, unsur tersebut dapat dicari dan ditemukan berdasarkan atributatributnya.

SIG menghubungkan sekumpulan unsur-unsur peta dengan atributnya didalam satuan-satuan yang disebut layer. Sungai, bangunan, jalan, laut batas-batas administratif, perkebunan dan hutan merupakan contoh layer. Kumpulan layer tersebut membentuk basis data SIG. dengan demikian, perancangan basis data merupakan hal yang esensial didalam SIG. Rancangan basis data akan menentukan efektifitas dan efisiensi proses-proses masukan, pengelolaan dan keluaran SIG (Prahasta, 2009).

\section{Hipotesis}

Berdasarkan uraian di atas, maka dapat diambil hipotesis sebagai berikut: Kecamatan patuk merupakan daerah dengan mayoritas kerawanan terhadap tanah longsor kategori tinggi.

\section{Bahan dan Alat Penelitian}

Bahan yang digunakan dalam penelitian ini adalah kondisi Curah Hujan Kecamatan Patuk, kondisi Geologi Kecamatan Patuk, kondisi Jenis Tanah Kecamatan Patuk, kondisi Penutupan Lahan Kecamatan Patuk dan kondisi Kemiringan Lereng Kecamatan Patuk. Data primer juga akan diukur dalam penelitian ini untuk parameter jenis tanah dan kemiringan lahan di daerah Kecamatan Patuk. Program yang digunakan dalam pengolahan data dan penyusunan hasil penelitian adalah ArcGIS 10.3 dan Microsoft Word 2010.

\section{Metode Penelitian Pengumpulan Data}

Data yang digunakan dalam proses penelitian terdiri dari beberapa jenis data dasar berupa peta seperti tercantum pada Tabel 1.

Sumber: BBSDLP (2009) 


\begin{tabular}{|c|l|c|}
\hline No. & \multicolumn{1}{|c|}{ Jenis Data } & Sumber Data \\
\hline 1 & Kondisi Curah Hujan Kecamatan Patuk & Bappeda \\
\hline 2 & Kondisi Geologi Kecamatan Patuk & Bappeda \\
\hline 3 & Kondisi Jenis Tanah Kecamatan Patuk & Bappeda \\
\hline 4 & Kondisi Penutupan Lahan Kecamatan Patuk & Bappeda \\
\hline 5 & Kondisi Kemiringan Lereng Kecamatan Patuk & Bappeda \\
\hline
\end{tabular}

\section{Pengolahan Data Spasial}

Dalam pengolahan tahap awal setiap data harus dijadikan peta digital. Data analog juga harus dijadikan peta digital format vektor. Peta digital format vektor merupakan salah satu jenis data masukan yang disimpan dalam bentuk garis, titik dan poligon. Proses pemasukan data-data dilakukan melalui seperangkat computer dengan software ArcGIS 10.3.

\section{Analisis Data}

Analisis kerawanan tanah longsor dilakukan setelah peta-peta tematik yaitu kondisi Curah Hujan, kondisi Jenis Tanah, kondisi Geologi, kondisi Penutupan Lahan dan kondisi Kemiringan Lahan wilayah tersebut tersedia dan siap dalam bentuk peta digital. Setiap jenis peta tersebut dilakukan klasifikasi berdasarkan skor serta diberi bobot kemudian ditumpangsusunkan (Overlay). Overlay tersebut dilakukan dengan software ArcGIS 10.3, pada proses overlay setiap parameter memiliki klasifikasi skor yang dikalikan dengan bobot masing-masing parameter, kemudian hasil perkalian skor dan bobot tersebut dijumlahkan.
Penentuan skor tiap kelas parameter didasarkan pada hasil penelitian yang dilakukan oleh BBSDLP (2009). Skor dari yang paling tinggi sampai yang paling rendah sebanding dengan tingkat bahaya yang tanah longsor akan ditimbulkan. Semakin tinggi skor, maka semakin tinggi pula potensi tanah longsor yang akan terjadi.

Dalam penentuan skor curah hujan, BBSDLP (2009) membagi menjadi lima kelas, semakin besar curah hujan yang turun maka semakin tinggi skor curah hujan tersebut seperti tercantum pada Tabel 2.

Tabel 2. Klasifikasi curah hujan (mm/tahun)

\begin{tabular}{|c|c|c|c|c|}
\hline & Kelas Parameter & Curah hujan (mm/tahun) & \multirow{3}{*}{$\begin{array}{c}\text { Bobot } \\
20 \%\end{array}$} & Skor \\
\hline a & Sangat Basah & $2001-2500$ & & 4 \\
\hline $\mathrm{b}$ & Basah & $1500-2000$ & & 2 \\
\hline
\end{tabular}

Sumber: BBSDLP (2009)

Skoring dan pembobotan pada tiap jenis batuan dapat dilihat pada Tabel 3 . Tabel 3. Klasifikasi jenis batuan

\begin{tabular}{|c|c|c|c|c|}
\hline & Kelas Parameter & $\begin{array}{c}\text { Kepekaan Terhadap } \\
\text { Longsor }\end{array}$ & \multirow{4}{*}{$\begin{array}{c}\text { Bobot } \\
25 \%\end{array}$} & Skor \\
\hline a & Kepekaan terhadap longsor & Tinggi & & 5 \\
\hline $\mathrm{b}$ & Kepekaan terhadap longsor & Sedang & & 3 \\
\hline $\mathrm{c}$ & Kepekaan terhadap longsor & Rendah & & 1 \\
\hline
\end{tabular}

Sumber: BBSDLP (2009)

Dalam bencana tanah longsor, faktor kemiringan lahan sangat berpengaruh, semakin tinggi dan semakin tegak lereng maka 
kemungkinan terjadinya longsoran semakin tinggi. Skor dan bobot parameter kemiringan lahan dapat dilihat pada Tabel 4.

Tabel 4. Skor parameter kemiringan lahan

\begin{tabular}{|c|c|c|c|}
\hline & $\begin{array}{c}\text { Kelas Parameter } \\
\text { Kemiringan Lahan \% }\end{array}$ & \multirow{6}{*}{$\begin{array}{c}\text { Bobot } \\
20 \%\end{array}$} & Skor \\
\hline $\mathrm{a}$ & $>45$ & & 5 \\
\hline $\mathrm{b}$ & $25-45$ & & 4 \\
\hline $\mathrm{c}$ & $15-25$ & & 3 \\
\hline d & $8-15$ & & 2 \\
\hline e & $<8$ & & 1 \\
\hline
\end{tabular}

Sumber: BBSDLP (2009)

Kondisi penutupan lahan sebagai faktor penyebab tanah longsor berkaitan dengan kestabilan lahan, kontrol terhadap kejenuhan air serta kekuatan ikatan partikel tanah. Skor dan bobot parameter penutupan lahan dapat dilihat pada Tabel 5 .

Tabel 5. Kondisi penutupan lahan

\begin{tabular}{|c|c|c|c|}
\hline & $\begin{array}{l}\text { Kelas Parameter } \\
\text { Tutupan Lahan }\end{array}$ & \multirow{6}{*}{$\begin{array}{l}\text { Bobot } \\
20 \%\end{array}$} & Sko \\
\hline a & Tegalan, sawah & & 5 \\
\hline b & Semak belukar & & 4 \\
\hline c & Hutan dan perkebunan & & 3 \\
\hline d & Permukiman & & 2 \\
\hline $\mathrm{e}$ & Tambak, waduk, perairan & & 1 \\
\hline
\end{tabular}

Sumber: BBSDLP (2009)

Penentuan skor jenis tanah dilakukan berdasarkan tingkat kepekaan terhadap longsor jenis tanah tersebut, semakin peka terhadap longsor maka semakin tinggi skor yang diberikan. Skor dan bobot parameter kondisi tanah dapat dilihat pada Tabel 6.

Tabel 6. Klasifikasi kondisi tanah

\begin{tabular}{|c|c|c|c|c|}
\hline & Kelas Parameter & $\begin{array}{c}\text { Kepekaan Terhadap } \\
\text { Longsor }\end{array}$ & \multirow{4}{*}{$\begin{array}{c}\text { Bobot } \\
10 \%\end{array}$} & Skor \\
\hline a & Kepekaan terhadap longsor & Tinggi & & 5 \\
\hline $\mathrm{b}$ & Kepekaan terhadap longsor & Sedang & & 3 \\
\hline $\mathrm{c}$ & Kepekaan terhadap longsor & Rendah & & 1 \\
\hline
\end{tabular}

Sumber: BBSDLP (2009)

Acuan yang digunakan untuk menganalisis kerawanan longsor adalah model pendugaan yang mengacu pada penelitian BBSDLP (2009) dengan formula sebagai berikut

Skor Total $=(0,2 \times$ Faktor Curah Hujan $)+(0,25 \times$ Faktor jenis batuan $)+(0,2 \times$ Faktor Kemiringan Lereng $)+(0,1$ Faktor Penutupan Lahan) + (0,1 Faktor Jenis Tanah)

Skor hasil akhir overlay dibagi menjadi tiga kelas kerawanan longsor yaitu : rendah, sedang dan tinggi berdasarkan jumlah skor akhir dengan penentuan selang skor :

a. Kerawanan rendah : daerah dengan hasil skor akhir 1

b. Kerawanan sedang : daerah dengan hasil skor akhir 2

c. Kerawanan tinggi : daerah dengan hasil skor akhir 3

Setelah diperoleh peta sebaran kawasan rawan bencana tanah longsor di Kecamatan Patuk lalu data yang terangkum dalam peta sebaran tersebut 
dikaji berdasarkan teknik konservasi yang harus dilakukan terhadap kawasan tersebut. Setiap faktor yang mempengaruhi terjadinya bencana tanah longsor harus dicegah dengan tindakan konservasi secara vegetatif ataupun mekanik. Maka akan didapatkan hasil kajian dari data tersebut yang dapat bermanfaat secara nyata pada penerapannya di lapangan.

\section{HASIL}

Komponen yang digunakan untuk memperoleh tingkat risiko bencana suatu kawasan dengan mengoverlay data dari 5 parameter yang didapat yaitu kondisi curah hujan, kondisi batuan, kondisi kemiringan lereng, jenis tanah dan kondisi penggunaan lahan. Selain tingkat risiko, kajian diharapkan mampu menghasilkan peta risiko untuk setiap lokasi yang ada di Kecamatan Patuk. Kajian dan peta risiko bencana ini harus mampu menjadi dasar yang memadai bagi kecamatan untuk menyusun kebijakan penanggulangan bencana. Ditingkat administrasi yang lebih tinggi, hasil pengkajian diharapkan dapat dijadikan dasar yang kuat dalam perencanaan upaya pengurangan risiko bencana.

Letak, Luas dan Batas Wilayah

\begin{tabular}{lrr}
\multicolumn{1}{c}{ Bukit } & Patuk & \multicolumn{2}{c}{ Gunungkidul } \\
terletak di & perbatasan & antara \\
Kabupaten & Gunungkidul & dan
\end{tabular}

Kabupaten Bantul yang memiliki topografi khas pegunungan dengan kontur yang bervariasi (Rahayu, 2012).

Kecamatan Patuk memiliki luas daerah sekitar 72,04 $\mathrm{km}^{2}$ yang merupakan $4,85 \%$ dari seluruh luas daerah di Kabupaten Gunungkidul. Kecamatan Patuk sebelah utara berbatasan dengan Kecamatan Gedangsari, sebelah selatan berbatasan dengan Kecamatan Playen, Sebelah timur berbatasan dengan Kecamatan Gedangsari dan sebelah barat berbatasan dengan Kecamatan Piyungan dan Bantul (BPS, 2015).

Daerah penelitian terletak di lereng perbukitan dengan kemiringan lereng yang beragam namun didominasi oleh kemiringan lereng miring hingga terjal yang mengakibatkan semakin rawan terjadi bencana tanah longsor. Kejadian bencana tanah longsor pernah terjadi pada bulan Februari 2015 yang sangat merugikan bagi penduduk di Kecamatan Patuk.

Iklim dan Curah Hujan

Curah hujan rata-rata Kecamatan Patuk pada tahun 2015 berada pada rentang angka $1501-2500$. Bulan basah pada Kecamatan Patuk berkisar $4-6$ bulan, sedangkan bulan kering berkisar antara $4-5$ bulan. Musim hujan dimulai pada bulan Nopember dan berakhir pada bulan Mei. Puncak curah hujan dicapai pada bulan Januari 
- Februari. Wilayah Kecamatan Patuk merupakan wilayah yang memiliki curah hujan cukup tinggi (BPS, 2015).

Sebagai salah satu parameter untuk menentukan wilayah rawan longsor, faktor-faktor curah hujan seperti besarnya curah hujan, intensitas hujan dan distribusi curah hujan akan menentukan seberapa besar peluang terjadinya longsor dan dimana longsor itu akan terjadi. Intensitas dan distribusi curah hujan di Kecamatan Patuk dapat dilihat pada Tabel 7. Dan Gambar 10.

Tabel 7. Intensitas dan distribusi curah hujan

\begin{tabular}{|c|c|c|}
\hline DESA & CURAH HUJAN (mm/tahun) & LUAS AREA $\left(\mathrm{m}^{2}\right)$ \\
\hline \multirow[t]{2}{*}{ Beji } & $1500-2000 \mathrm{~mm} /$ tahun & $555,215.90$ \\
\hline & $2000-2500 \mathrm{~mm} / \mathrm{tahun}$ & $5,008,739.81$ \\
\hline \multirow[t]{2}{*}{ Bunder } & $1500-2000 \mathrm{~mm} /$ tahun & $2,306,837.90$ \\
\hline & $2000-2500 \mathrm{~mm} / \mathrm{tahun}$ & $3,096,223.18$ \\
\hline Nglanggeran & $2000-2500 \mathrm{~mm} / \mathrm{tahun}$ & $7,280,585,50$ \\
\hline \multirow{2}{*}{ Nglegi } & $1500-2000 \mathrm{~mm} /$ tahun & $3,213,575.38$ \\
\hline & $2000-2500 \mathrm{~mm} / \operatorname{tahun}$ & $9,698,939.01$ \\
\hline Ngoro Oro & $2000-2500 \mathrm{~mm} / \mathrm{tahun}$ & $7,203,835.79$ \\
\hline \multirow[t]{2}{*}{ Patuk } & $1500-2000 \mathrm{~mm} / \mathrm{tahun}$ & $2,568,805.23$ \\
\hline & $2000-2500 \mathrm{~mm} / \mathrm{tahun}$ & $26,285.80$ \\
\hline \multirow[t]{2}{*}{ Pengkok } & $1500-2000 \mathrm{~mm} / \mathrm{tahun}$ & $2,586,150,70$ \\
\hline & $2000-2500 \mathrm{~mm} /$ tahun & $342,956.76$ \\
\hline Putat & $2000-2500 \mathrm{~mm} / \mathrm{tahun}$ & $6,838,905.12$ \\
\hline \multirow[t]{2}{*}{ Salam } & $1500-2000 \mathrm{~mm} /$ tahun & $2,507,045.33$ \\
\hline & $2000-2500 \mathrm{~mm} /$ tahun & $2,319,733.83$ \\
\hline Semoyo & $1500-2000 \mathrm{~mm} / \mathrm{tahun}$ & $6,302,681.83$ \\
\hline \multirow[t]{2}{*}{ Terbah } & $1500-2000 \mathrm{~mm} / \mathrm{tahun}$ & $4,415,881.89$ \\
\hline & $2000-2500 \mathrm{~mm} /$ tahun & $5,768,241.50$ \\
\hline
\end{tabular}

Sumber : Peta curah hujan Kecamatan Patuk (BAPPEDA)
Berdasarkan klasifikasi curah hujan di atas, Kecamatan Patuk memiliki 2 kelas curah hujan yaitu 1500-2000 mm/tahun dan 2000-2500 $\mathrm{mm} / \mathrm{tahun}$. Curah hujan dengan intensitas 1500-2000 $\mathrm{mm} /$ tahun dengan luasan wilayah paling kecil terletak pada Desa Beji yaitu seluas $555,215.90 \mathrm{~m}^{2}\left(0,56 \mathrm{~km}^{2}\right)$ dan paling luas terletak di Desa Semoyo dengan wilayah seluas $6,302,681.83 \mathrm{~m}^{2}(6,3$ $\mathrm{km}^{2}$ ). Untuk curah hujan dengan intensitas 2000-2500 $\mathrm{mm} /$ tahun dengan luasan wilayah paling kecil terletak pada Desa Patuk yaitu seluas $26,285.80 \mathrm{~m}^{2}\left(0,026 \mathrm{~km}^{2}\right)$ dan paling luas terletak di Desa Nglegi dengan wilayah seluas $9,698,939.01 \mathrm{~m}^{2}(9,6$ $\mathrm{km}^{2}$ ).

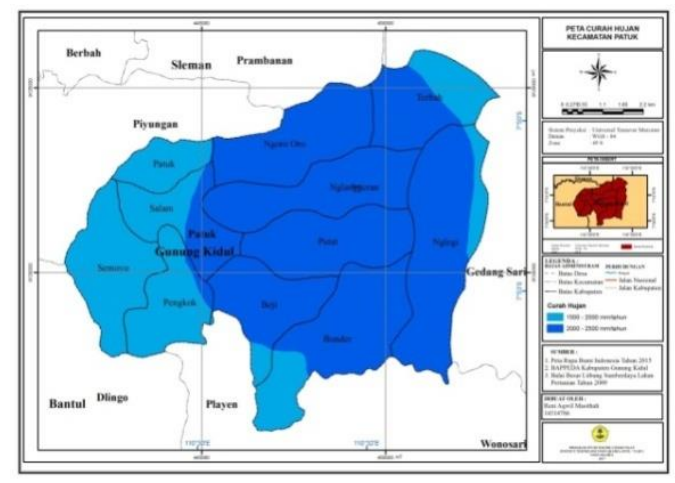

Gambar 10. Peta curah hujan Kecamatan Patuk

Jenis Batuan

Zona Pegunungan Selatan dapat dibagi menjadi tiga subzona, yaitu Subzona Baturagung, Subzona Wonosari dan Subzona Gunung Sewu. 
Subzona Baturagung terutama terletak di bagian utara dimana Kecamatan Patuk termasuk dalam subzona tersebut. Subzona Baturagung ini membentuk relief paling kasar dengan sudut lereng antara $10^{\circ}-30^{\circ}$ dan beda tinggi sekitar 200-700 meter serta hampir seluruhnya tersusun oleh batuan asal gunung api.

Terdapat 6 jenis formasi batuan pada Kecamatan Patuk yaitu, Formasi Nglanggaran, Formasi Kebonbutak, Formasi Nampol, Formasi Sambipitu, Formasi Semilir dan Formasi Wonosari. Jenis dan distribusi batuan di Kecamatan Patuk dapat dilihat pada Tabel 8. Dan Gambar 11.

Tabel 8. Jenis dan distribusi batuan

\begin{tabular}{|c|c|c|}
\hline DE SA & FORMASI BATUAN & LUAS AREA $\left(\mathrm{m}^{2}\right)$ \\
\hline \multirow[t]{4}{*}{ Beji } & Formasi Ngalang gr an & $13,841.47$ \\
\hline & SambipituFormation & $3,343,811.57$ \\
\hline & Nampol Formation & $287,935.60$ \\
\hline & Wonosari Fomation & $1,918,376.80$ \\
\hline \multirow{2}{*}{ Bunder } & SambipituFormation & $3.819,512.63$ \\
\hline & Wonosari Formation & $5,582,479.28$ \\
\hline Nglanggeran & Form asi Ngalanggr an & $7,280,585.50$ \\
\hline \multirow{4}{*}{ Nglegj } & Semilir Formation & $1,258,032.50$ \\
\hline & Form asi Ngalanggr an & $4,471,012,87$ \\
\hline & SambipituFormation & $2,714,312.61$ \\
\hline & Wonosari Formation & $2,469,129.00$ \\
\hline \multirow{2}{*}{ NgoroOro } & Semilir Formation & $2,704.788 .23$ \\
\hline & Formasi Ngalanggr an & $4,499,047.57$ \\
\hline \multirow[t]{2}{*}{ Patulk } & Semilir Formation & $492,520.63$ \\
\hline & Form asi Ngalanggr an & $2,102,570.37$ \\
\hline \multirow[t]{3}{*}{ Pengkok } & Formasi Ngalangran & $1,873,572.94$ \\
\hline & SambipituFormation & $2,922,853.35$ \\
\hline & Nampol Formation & $132,692.14$ \\
\hline \multirow[t]{2}{*}{ Putat } & Formasi Ngalanggr an & $3.850,516.55$ \\
\hline & SambipituFormation & $2,988,348.53$ \\
\hline \multirow[t]{2}{*}{ Salam } & Formasi Ngalangran & $4,521.838 .54$ \\
\hline & SambipituFormation & $296,946.62$ \\
\hline \multirow{3}{*}{ Semoyo } & Semilir Formation & $5,436,76$ \\
\hline & Formasi Ngalanggr an & $6,053,914,42$ \\
\hline & SambipituFormation & $383,330.63$ \\
\hline \multirow[t]{3}{*}{ Terbah } & Semilir Formation & $4,656,142,47$ \\
\hline & Kebobutak Formation & $603,482.70$ \\
\hline & Form asi Ngalanggr an & $793,608.16$ \\
\hline
\end{tabular}

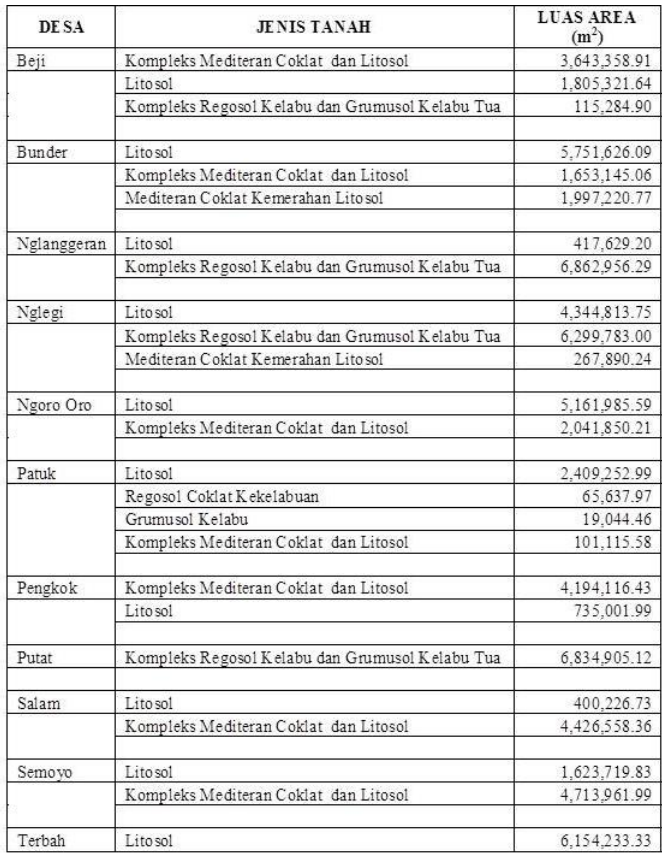

Sumber: Peta Jenis Batuan Kecamatan Patuk (BAPPEDA)

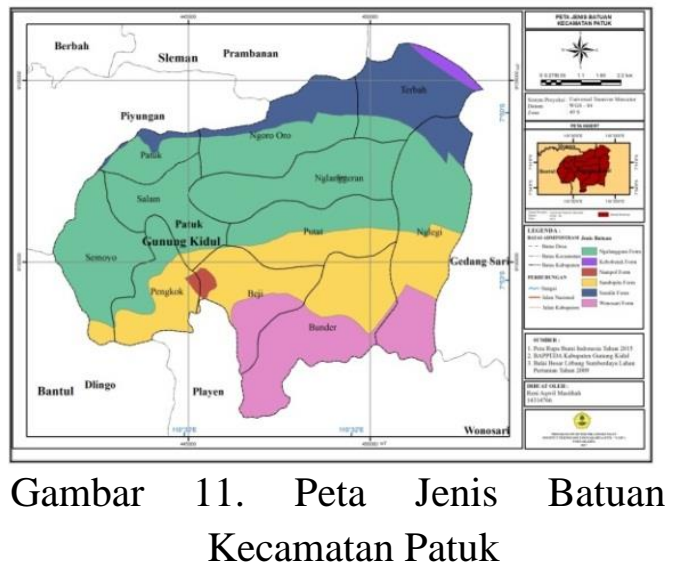

Jenis Tanah

Kondisi geologis yang berbeda di Kabupaten Gunungkidul berpengaruh terhadap pembentukan tanah di masing-masing kecamatan. Untuk Kecamatan Patuk terdapat beberapa jenis tanah yaitu, latosol 
yang merupakan batuan induk kompleks sedimen tufan dan batuan vulkanik, yang terletak pada wilayah bergunung-gunung dan asosiasi latosol merah dan litosol, dengan bahan induk tufan dan batuan vulkanik intermediet, bentuk wilayah yang bergelombang sampai berbukit.

Tabel 9. Jenis dan distribusi tanah

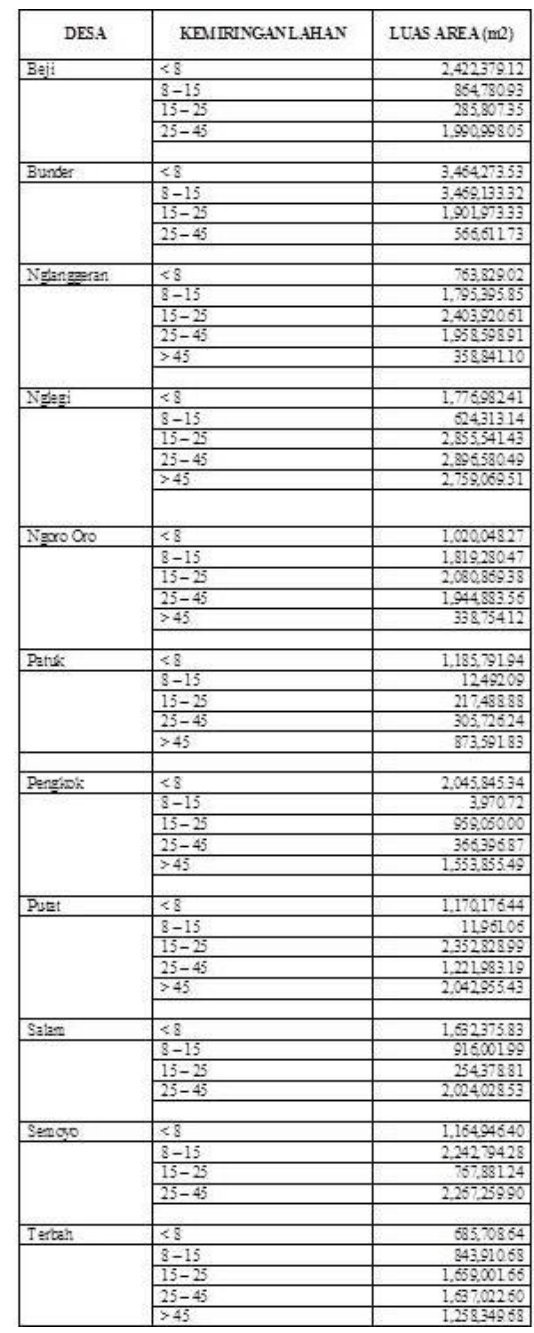

Sumber: Peta Jenis Tanah Kecamatan Patuk (BAPPEDA)

Tanah grumusol atau margalith adalah tanah yang berbentuk dari batu kapur dan material halus berlempung. Jenis tanah ini berwarna kelabu hitam dan bersifat subur, tersebar di Jawa Tengah, Jawa Timur, Madura, Nusa Tenggara, dan Sulawesi Selatan. Tanah grumusol pada umumnya dengan kadar liat lebih dari $30 \%$ bersifat mengembang dan mengerut, jika musim kering tanah keras dan retak-retak karena mengerut, jika musim basah tanah menjadi lengket, tanah jenis ini digolongkan kedalam jenis dengan kepekaan tinggi terhadap longsor (Surbadja S dkk, 2014). Daerah dengan jenis tanah grumusol ini yaitu Desa Beji, DesaNglanggeran, Desa Nglegi, Desa Patuk dan Desa Putat.

Tanah Regosol, jenis tanah ini berbentuk dari bahan induk abu dan pasir vulkan intermedier. Bentuk wilayahnya berombak sampai bergunung. Tanah regosol belum jelas menempatkan perbedaan horizonhorizon. Tekstur tanah ini biasanya kasar, tanpa ada struktur tanah, konsistensi lepas sampai gembur dan keasaman tanah dengan $\mathrm{pH}$ sekitar 6-7. Tanah jenis ini digolongkan kedalam jenis dengan kepekaan tinggi terhadap longsor (Surbadja S dkk, 2014). Wilayah dengan jenis tanah regosol ini terletak pada Desa Beji, Desa 
Nglanggeran, Desa Nglegi, Desa Patuk dan Desa Putat.

Tanah litosol, jenis tanah ini biasa disebut 'laterit'. Penampang umumnya tebal, tanah atasnya mengandung beberapa persen bahan organik. Berwarna coklat, kuning, hingga kemerahan. Bersifat berbutir, teguh, mantap, mengandung kaolinit, bersifat tidak plastis, dan dapat diolah pertanian sepanjang tahun. Jenis tanah ini bersifat meniris, tahan terhadap erosi (Surbadja S dkk, 2014). Tanah jenis ini digolongkan kedalam jenis dengan kepekaan rendah terhadap longsor. Jenis tanah ini tersebar diseluruh Kecamatan Patuk dengan luasan yang berbeda-beda disetiap desa. Wilayah dengan jenis tanah litosol paling luas yaitu Desa Terbah yaitu seluas 6,154,233.33 $\mathrm{m}^{2}(6,15$ $\mathrm{km}^{2}$ ) sedangkan wilayah dengan tanah jenis litosol paling kecil yaitu Desa Salam yaitu seluas $400,226.73 \mathrm{~m}^{2}(0,4$ $\mathrm{km}^{2}$

Gambar 12. Peta jenis tanah berdasarkan kepekaan terhadap longsor Kecamatan Patuk

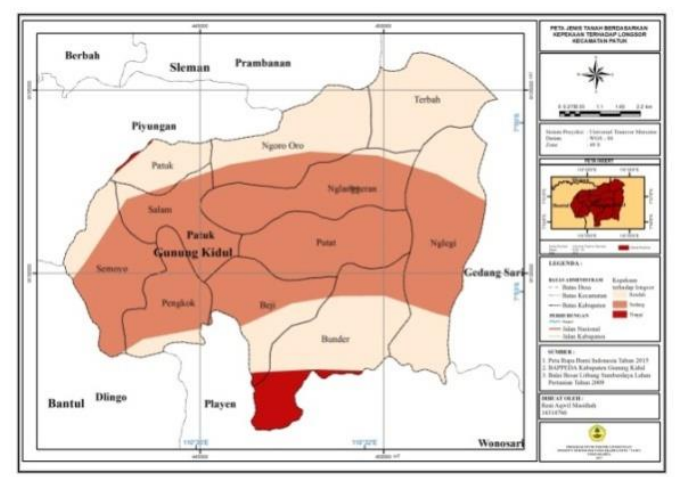

Kemiringan Lahan

Subzona fisiografi Pegunungan Baturagung yang meliputi daerah Kecamatan Patuk, secara dominan wilayah tersebut berupa perbukitanpegunungan, dengan ketinggian berkisar 200-700 meter dan kelerengan berkisar 8 - >40\%. Berdasarkan data kemiringan lahan Kecamatan Patuk, didapatkan klasifikasi kemiringan lahan datar (kemiringan 0-8\%), landai (kemiringan $\quad(8-15 \%)$, terjal (kemiringan 15-25\%), curam (kemiringan 25-45\%) dan sangat curam (kemiringan $>45 \%$ ). Luas dan distribusi masing-masing kelas kemiringan lahan dapat dilihat pada Tabel 10. dan Gambar 6.

Wilayah dengan kemiringan lahan $<8 \%$ (datar) memiliki areal penyebaran terluas di Desa bunder yaitu $3,46 \mathrm{~km}^{2}$. Wilayah dengan kemiringan lahan $8-15 \%$ (landai) terluas terletak di Desa Bunder yaitu seluas $\quad 3,46 \quad \mathrm{~km}^{2}$. Wilayah dengankemiringan lahan $15-25 \%$ (terjal) terluas terletak di Desa Nglegi yaitu seluas $2,85 \mathrm{~km}^{2}$. Wilayah dengan kemiringan lahan $25-45 \%$ (curam) terluas terletak di Desa Nglegi yaitu seluas $2,89 \mathrm{~km}^{2}$. Wilayah dengan kemiringan lahan $>45 \%$ (sangat curam terluas terletak di Desa Nglegi yaitu seluas $2,75 \mathrm{~km}^{2}$, wilayah ini umumnya berada di tepi pegunungan ataupun 
daerah aliran sungai yaitu di sekitar tebing sungai.

Wilayah dengan lereng $>45 \%$ (sangat curam) merupakan wilayah yangsangat berpotensi untuk terjadinya tanah longsor. Dalam bencana tanah longsor,faktor kemiringan lahan sangat berpengaruh, semakin tinggi dan semakin tegaklereng maka kemungkinan terjadinya longsoran semakin tinggi. Hal tersebutberkaitan dengan kestabilan lereng, semakin curam lereng maka lereng akanmengalami tekanan beban yang lebih besar sehingga makin tidak stabil untukmenahan beban di atasnya dari pengaruh gravitasi bumi.

Gambar 13. Peta kemiringan lereng Kecamatan Patuk

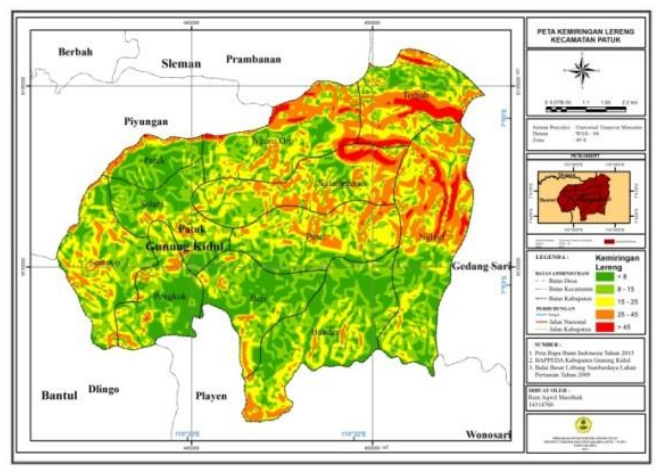

Penggunaan Lahan

Penutupan lahan di Kecamatan Patuk terbagi kedalam Sembilan tipe yaitu : air tawar, belukar/semak, gedung, kebun, pemukiman, rumput, sawah irigasi, sawah tadah hujan dan tegalan.
Tabel 10. Tipe dan distribusi penutupan lahan

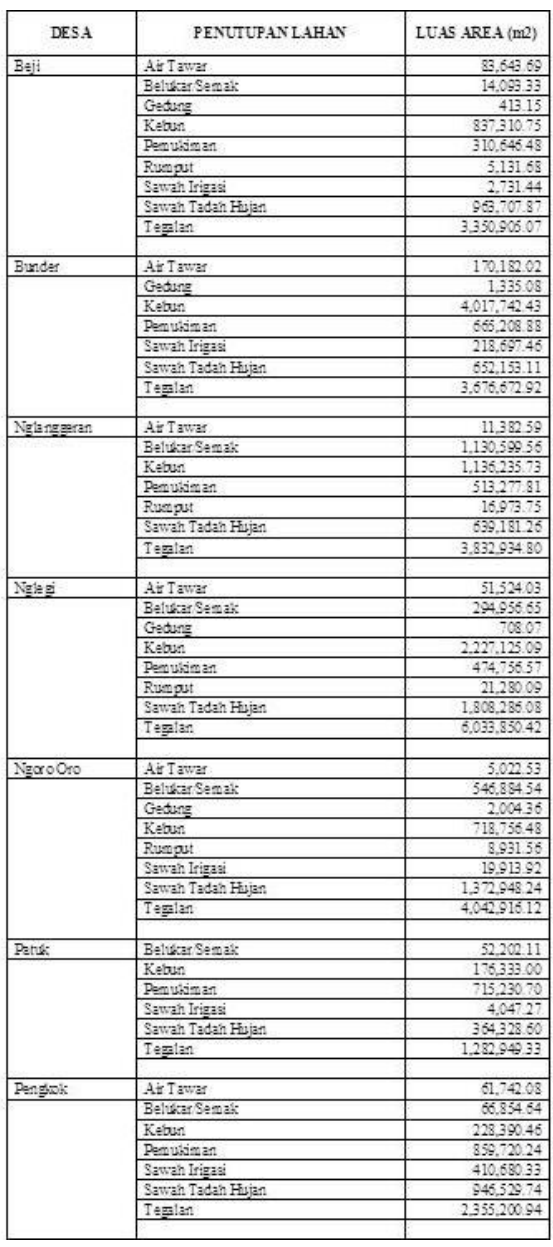




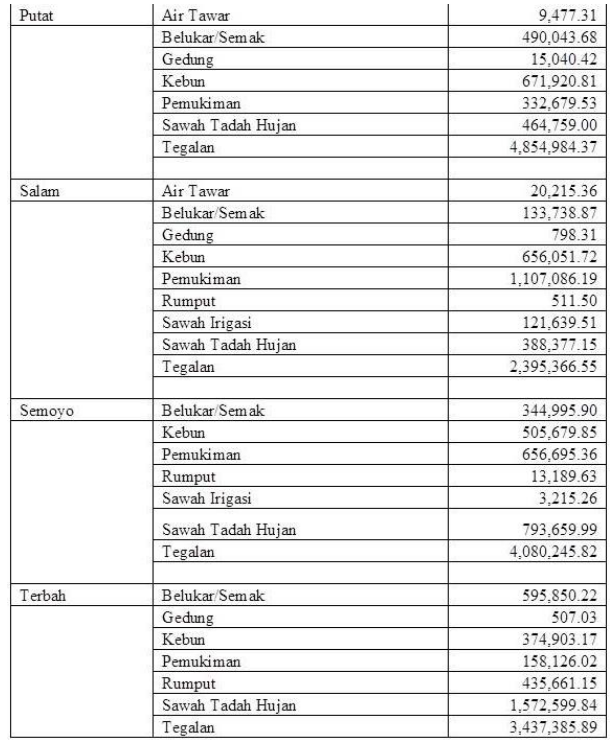

Sumber: Peta Penggunaan Lahan Kecamatan Patuk (BAPPEDA)

Penutupan lahan di suatu wilayah erat hubungannya dengan kondisi ekonomi dan tipe masyarakat yang tinggal di wilayah tersebut. Dapat dilihat pada tabel 11. bahwa penggunaan lahan di Kecamatan Patuk sebagian besar diperuntukkan untuk tegalan, sawah tadah hujan dan kebun. Berdasarkan tabel di atas dapat diketahui bahwa sebagian besar mata pencaharian masyarakat Kecamatan Patuk berasal dari mengelola sawah, kebun dan tegalan mereka.

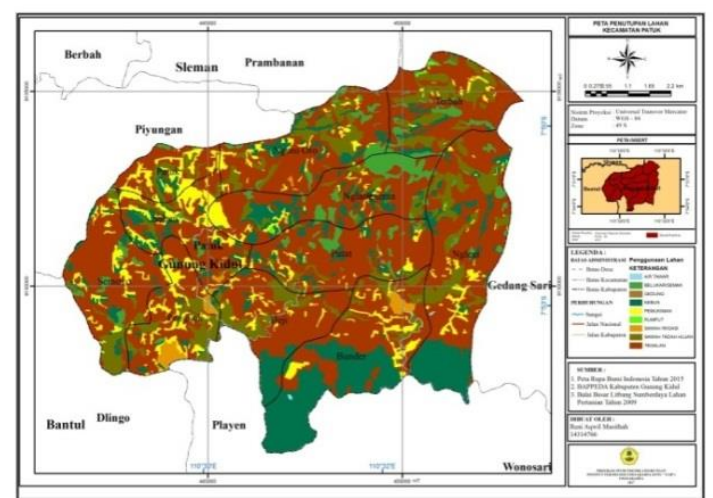

Gambar 14. Peta penggunaan lahan Kecamatan Patuk

Menurut Rahmat (2010) kondisi penutupan lahan sebagai faktor penyebab tanah longsor berkaitan dengan kestabilan lahan, kontrol terhadap kejenuhan air serta kekuatan ikatan partikel tanah. Tipe penutupan lahan memiliki kontribusi yang berbeda-beda tergantung pada sifat dan kondisi penutupan lahan tersebut seperti bentuknya berupa bangunan atau tanaman, jenis tanaman, sifat tanaman, luasan penutupan lahan serta lokasi dimana penutupan lahan itu berada adalah hal-hal yang berpengaruh dalam penentuan kerawanan wilayah.

Lahan yang ditutupi hutan dan perkebunan relatif lebih bisa menjaga stabilitas lahan karena sistem perakaran yang dalam sehingga bisa menjaga kekompakkan antar partikel tanah serta partikel tanah dengan batuan dasar dan bisa mengatur limpasan dan resapan air ketika hujan. 
Sedangkan tegalan dan sawah memiliki vegetasi yang tidak bisa menjaga stabilitas permukaan karena bersifat tergenang, serta memiliki sistem perakaran yang dangkal sehingga kurang menjaga kekompakkan partikel tanah. Pada lahan dengan tipe penutupan lahan demikianlah tanah longsor seringkali terjadi.

Distribusi Kawasan Rawan Tanah Longsor

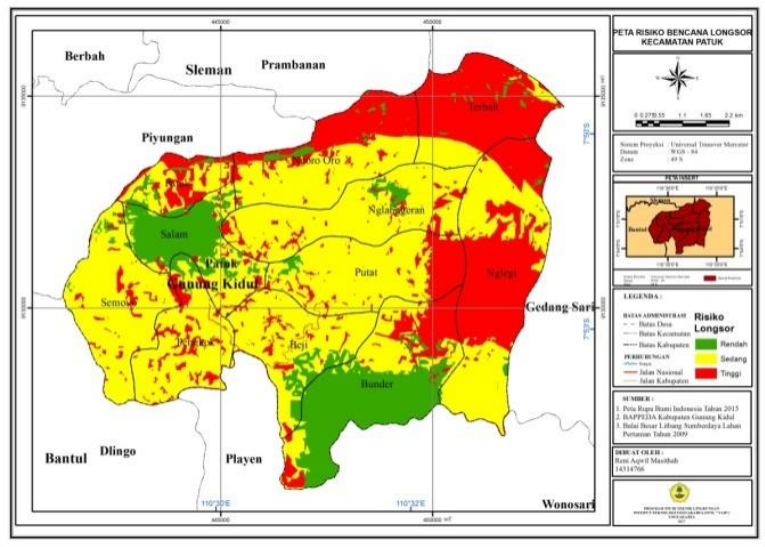

Gambar 15. Peta risiko bencana tanah longsor Kecamatan Patuk

Hasil analisis kerawanan tanah longsor dibagi kedalam tiga kelas kerawanan longsor yaitu wilayah dengan tingkat kerawanan rendah, sedang dan tinggi dengan gambaran distribusi spasial dapat dilihat pada Tabel 12. dan Gambar 15.
Tabel 12. Luas dan distribusi tingkat kerawanan tanah longsor

\begin{tabular}{|c|c|c|}
\hline DESA & TINGKAT RISIKO & LUAS.AREA $\left(\mathrm{m}^{2}\right)$ \\
\hline \multirow[t]{3}{*}{ Beji } & Rendah & $693,673.10$ \\
\hline & Sedang & $4,386,992.91$ \\
\hline & Tinggi & $483,299.43$ \\
\hline \multirow[t]{3}{*}{ Bunder } & Rendah & $5,294,544.61$ \\
\hline & Sedang & $2,328,902,11$ \\
\hline & Tinggi & $1,778,545.19$ \\
\hline \multirow[t]{3}{*}{ Nglanggeran } & Rendah & $285,780.73$ \\
\hline & Sedang & $6,314,232,34$ \\
\hline & Tinggi & $680,572.43$ \\
\hline & & \\
\hline \multirow[t]{3}{*}{\begin{tabular}{|l} 
Nglegi \\
\end{tabular}} & Rendah & $106,713.99$ \\
\hline & Sedang & $4,862,265.06$ \\
\hline & \begin{tabular}{|l|} 
Tinggi \\
\end{tabular} & $5,943,507.93$ \\
\hline \multirow[t]{3}{*}{ Ngoro Oro } & Rendah & 268.973 .05 \\
\hline & Sedang & $4,021,086.20$ \\
\hline & \begin{tabular}{|l} 
Tinggi \\
\end{tabular} & $2,913,776.56$ \\
\hline \multirow[t]{3}{*}{ Patuk: } & Rendah & $327,355.89$ \\
\hline & Sedang & $1,218,039.02$ \\
\hline & \begin{tabular}{|l|} 
Tinggi \\
\end{tabular} & $1,049,696.09$ \\
\hline \multirow{3}{*}{\begin{tabular}{|l} 
Pengkok \\
\end{tabular}} & Rendah & $208,059.34$ \\
\hline & \begin{tabular}{|l} 
Sedang \\
\end{tabular} & $3,900,594.67$ \\
\hline & \begin{tabular}{|l} 
Tingle \\
\end{tabular} & $820,464.42$ \\
\hline \multirow{3}{*}{\begin{tabular}{|l|} 
Putat \\
\end{tabular}} & Bends & $130,543,50$ \\
\hline & \begin{tabular}{|l} 
Rencan \\
Sedang
\end{tabular} & $\begin{array}{r}1.20 .04 .300 \\
5.212 .855 .49\end{array}$ \\
\hline & \begin{tabular}{|l} 
Ting gi \\
\end{tabular} & $1,495,506,13$ \\
\hline \multirow{3}{*}{ Salam } & Rendah & 2750.44967 \\
\hline & \begin{tabular}{|l} 
Renoan \\
Sedang \\
\end{tabular} & $\frac{2,120,449,01}{1.764,875,31}$ \\
\hline & \begin{tabular}{|l|} 
Tinggi \\
\end{tabular} & $304,420,18$ \\
\hline \multirow[t]{3}{*}{\begin{tabular}{|l|} 
Semovo \\
\end{tabular}} & Rendah & 131.452 .74 \\
\hline & Sedang & $5,701,473.91$ \\
\hline & \begin{tabular}{|l} 
Tinggi \\
\end{tabular} & $477,755.17$ \\
\hline \multirow[t]{3}{*}{ Terbah } & Rendah & $140,930.35$ \\
\hline & \begin{tabular}{|l} 
Sedang \\
\end{tabular} & $1,074,447.04$ \\
\hline & \begin{tabular}{|l} 
Tinggi \\
\end{tabular} & $4,968,855.87$ \\
\hline
\end{tabular}

Sumber: Peta risiko bencana tanah longsor Kecamatan Patuk

Berdasarkan hasil analisis tumpang susun (overlay) parameter yang ada di lokasi penelitian diperoleh klasifikasi kelas kerawanan longsor yaitu wilayah dengan tingkat kerawanan rendah, sedang dan tinggi.

Kelas kerawanan longsor rendah merupakan wilayah yang memiliki 
tingkat kerawanan rendah untuk terjadinya tanah longsor. Wilayah ini berada di Desa Bunder dengan luasan paling besar yaitu $5,29 \mathrm{~km}^{2}$. Desa yang memiliki kerawanan rendah lainnya yaitu Desa Salam dengan luasan 2,75 $\mathrm{km}^{2}$.

Kelas kerawanan longsor sedang merupakan wilayah yang secara umum memiliki tingkat kerawanan sedang untuk terjadinya tanah longsor. Wilayah dengan tingkat kerawanan sedang yang cukup luas terletak pada Desa Nglanggeran dengan luasan 6,31 $\mathrm{km}^{2}$, Desa Semoyo dengan luasan 5,70 $\mathrm{km}^{2}$ dan Desa Putat dengan luasan $5,21 \mathrm{~km}^{2}$.

Kelas kerawanan longsor tinggi merupakan wilayah yang secara umum memiliki tingkat kerawanan tinggi untuk terjadinya tanah longsor. Wilayah dengan tingkat kerawanan tinggi terletak pada Desa Nglegi dengan luasan 5,94 km², Desa Terbah dengan luasan 4,96 $\mathrm{km}^{2}$ dan Desa Ngoro ono dengan luasan $2,91 \mathrm{~km}^{2}$.

\section{PEMBAHASAN}

Terdapat 6 jenis formasi batuan pada Kecamatan Patuk yaitu, Formasi Nglanggaran, Formasi Kebobutak, Formasi Nampol, Formasi Sambipitu, Formasi Semilir dan Formasi Wonosari. Lokasi tipe Formasi Kebobutak terletak di Gunung Kebo dan Gunung Butak yang terletak di lereng dan kaki utara gawir
Baturagung. Litologi penyusun formasi ini di bagian bawah berupa batu pasir berlapis, batu lanau, batu lempung. Bagian atasnya berupa perselingan batu pasir dan batu lempung dengan sisipan tipis tuf asam. Karena pada formasi ini terdapat campuran batuan yang rentan bergerak yaitu pada batuan lempung yang memiliki kekedapan air cukup tinggi sehingga tingkat kesolidan rendah dan tidak rentan bergerak yaitu batu pasir yang kekedapan airnya rendah sehingga bisa berfungsi sebagai penahan air dalam tanah, maka untuk skoring dari jenis batuan formasi kebobutak dikategorikan sebagai sedang.

Untuk kategori kepekaan terhadap longsor sedang terdapat dua formasi batuan yang masuk di dalamnya yaitu Formasi Kebobutak dan Formasi Wonosari, sedangkan untuk kategori kepekaan terhadap tanah longsor rendah ada 4 formasi batuan yaitu Formasi Semilir, Formasi Nglanggaran, Formasi Sambipitu dan Formasi Nampol. Untuk 4 formasi yang masuk kedalam kategori kepekaan terhadap longsor rendah mayoritas merupakan batuan yang berasal dari gunungapi dan merupakan hasil endapan proses geodinamika. Batuan penyusun formasi-formasi tersebut beraneka ragam mulai batupasir kasar, breksi gunungapi, aliran lava andesit-basal, lava andesit, 
breksi batu apung dan serpih. Batuan penyusun formasi tersebut memiliki permeabilitas yang cukup tinggi sehingga dapat menahan air dengan baik dan memiliki kesolidan yang bagus .

Untuk jenis tanah di Kecamatan Patuk sesuai dengan yang digambarkan pada Gambar 12. pada daerah utara Kecamatan Patuk mayoritas jenis tanah memiliki kepekaan terhadap longsor rendah, jenis tanah di wilayah ini merupakan jenis regosol coklat keabuan dan kompleks regosol dengan campuan abu/pasir dan batu kapur. Tingkat permeabilitas pada jenis tanah ini cepat sehingga dapat dimasukkan ke dalam kategori rendah. Pada wilayah selatan dan timur Kecamatan Patuk yaitu Desa Bunder, Desa Nglegi, Desa Nglanggeran merupakan wilayah dengan jenis tanah yang sangat peka terhadap terjadinya bencana longsor. Jenis tanah di wilayah-wilayah tersebut terdiri dari tanah jenis grumusol dan regosol. Jenis tanah tersebut memiliki permeabilitas lambat sehingga ketika terjadi hujan dapat menimbulkan runoff yang cukup tinggi dan dapat meningkatkan terjadinya bencana longsor.

Setelah dilakukan overlay dari kelima parameter maka didapatkan peta distribusi risiko bencana tanah longsor Kecamatan Patuk. Seperti yang bisa dilihat pada Gambar 15 .
Wilayah yang memiliki tingkat kerawanan rendah berada di Desa Bunder dengan luasan paling besar yaitu $5,29 \mathrm{~km}^{2}$. Desa Bunder dengan lahan yang relatif landai merupakan daerah dengan mayoritas kebun dan tegalan, tanah di Desa Bunder yang mayoritas merupakan jenis litosol merupakan faktor-faktor yang mempengaruhi tingkat kerawanan rendah pada desa tersebut. Walaupun curah hujan pada Desa Bunder cukup tinggi yaitu $2000-2500 \mathrm{~mm} /$ tahun, air hujab tersebut akan menyerap dengan baik ke dalam tanah dikarenakan banyaknya perakaran kuat yang berasal dari perkebunan masyarakat dan tanah jenis litosol yang mudah menyerap dan menyimpan air. Desa yang memiliki kerawanan rendah lainnya yaitu Desa Salam dengan luasan $2,75 \mathrm{~km}^{2}$.

Wilayah dengan tingkat kerawanan sedang yang cukup luas terletak pada Desa Nglanggeran dengan luasan $6,31 \mathrm{~km}^{2}$, Desa Semoyo dengan luasan $5,70 \mathrm{~km}^{2}$ dan Desa Putat dengan luasan $5,21 \mathrm{~km}^{2}$. Curah hujan yang tinggi dengan intensitas 200-2500 mm/tahun dan sebagian daerah dengan kemiringan lereng curam dan sangat curam di beberapa desa ini merupakan faktor utama yang menyebabkan meningkatnya tingkat kerawanan di desa ini. Jenis tanah yang cukup peka terhadap erosi serta penggunaan lahan yang mayoritas 
diperuntukkan sebagai tegalan oleh masyarakat membuat tanah di beberapa desa tersebut mudah terpecah dan akan terbawa oleh air hujan yang akan membahayakan masyarakat sekitar.

Wilayah dengan tingkat kerawanan tinggi terletak pada Desa Nglegi dengan luasan 5,94 km², Desa Terbah dengan luasan $4,96 \mathrm{~km}^{2}$ dan Desa Ngoro ono dengan luasan 2,91 $\mathrm{km}^{2}$. Kemiringan lereng pada desadesa tersebut yang sangat curam akan sangat berbahaya ketika memasuki bulan basah. Dengan intensitas curah hujan yang tinggi akan menyebabkan mudah terjadinya longsor di daerah tersebut. Tindakan pencegahan yang dapat dilakukan yaitu pengalihan fungsi lahan tegalan menjadi kebun buah yang relatif tidak membutuhkan banyak air juga seperti halnya tegalan. Usaha lain yang bisa dilakukan yaitu pengolahan tanah menurut kontur dimana setiap jenis pengolahan tanah (pembajakan, pencangkulan dan pemerataan) mengikuti garis kontur sehingga terbentuk alur-alur dan jalur tumpukan tanah yang searah kontur dan memotong lereng. Alur-alur ini akan menghambat aliran air di permukaan dan mencegah erosi sehingga dapat menunjang konservasi di daerah tersebut. Pelaksanaan slope reshaping, pembuatan bronjong kawat dan webbing jute juga dapat dilakukan agar lereng terjal tidak mudah terjadi erosi. Slope reshapping dapat dilakukan pada daerah terjal dengan mengubah lereng menjadi lebih landai, mengubah lereng menjadi terasering, dan lain-lain. Tujuan dari slope reshaping yaitu mengurangi derajat kemiringan lereng sehingga dapat mengurangi tingkat kerawanan terjadinya bencana tanah longsor. Bronjong kawat merupakan usaha menguatkan tepian lereng atau pun tepian sungai yang rawan terjadi erosi.

Webbing jute atau yang dikenal dengan bronjong sabut kelapa yang dipadu dengan rumput akar wangi merupakan upaya pencegahan bencana yang rawan lingkungan. Penggunaan sabut kelapa sebagai bahan untuk penahan longsor lebih ramah lingkungan, karena disela-sela anyaman dapat ditanami rumput akar wangi. Dengan perpaduan tersebut, mampu menahan longsor hingga puluhan tahun.

Geocell merupakan salah satu jenis Geosynthetics yang terbuat dari HDPE yang didesain untuk menyeimbangkan/stabilisasi tanah dan juga berfungsi sebagai peningkat kinerja untuk bahan konstruksi standart, maupun sebagai pengontrol erosi pada tebing/lereng.

\section{Kesimpulan}

Berdasarkan hasil penelitian di Kecamatan Patuk, Kabupaten 
Gunungkidul maka dapat disimpulkan sebagai berikut:

1. Wilayah yang memiliki tingkat kerawanan rendah berada di Desa Bunder dengan luasan paling besar yaitu $5,29 \mathrm{~km}^{2}$. Kemiringan kereng yang landai dan banyaknya wilayah kebun menjadi faktor utama yang menjadikan desa ini memiliki resiko rendah terhadap bencana tanah longsor.

2. Wilayah dengan tingkat kerawanan sedang terletak pada Desa Nglanggeran dengan luasan $6,31 \mathrm{~km}^{2}$, Desa Semoyo dengan luasan $5,70 \mathrm{~km}^{2}$ dan Desa Putat dengan luasan $5,21 \mathrm{~km}^{2}$. Kemiringan di desa-desa tersebut merupakan kemiringan cukup curam, curah hujan tinggi berkisar 2000-2500 $\mathrm{mm} / \mathrm{tahun}$ dan banyaknya tegalan yang menyebabkan wilayah tersebut kebih rawan bencana tanah longsor.

3. Wilayah dengan tingkat kerawanan tinggi terletak pada Desa Nglegi dengan luasan 5,94 $\mathrm{km}^{2}$, Desa Terbah dengan luasan $4,96 \mathrm{~km}^{2}$ dan Desa Ngoro ono dengan luasan 2,91 $\mathrm{km}^{2}$. Kemiringan lereng yang mayoritas $>45 \%$, didukung dengan curah hujan tinggi berkisar 2000-2500 mm/tahun, jenis tanah regosol dan grumusol yang peka terhadap tanah longsor, penggunaan lahan yang sebagain besasr merupakan tegalan menjadikan wilayah tersebut berpotensi tinggi terjadinya bencana tanah longsor..

\section{Saran}

Berdasarkan hasil penelitian di Kecamatan Patuk, Kabupaten Gunungkidul maka saran yang dapat diberikan sebagai berikut:

1. Tindakan pencegahan yang dapat dilakukan yaitu pengalihan fungsi lahan tegalan menjadi kebun buah yang relatif tidak membutuhkan banyak air juga seperti halnya tegalan.

2. Pengadaan papan peringatan rawan bencana tanah longsor di jalan raya Kecamatan Patuk.

3. Pengolahan tanah menurut kontur dimana setiap jenis pengolahan tanah (pembajakan, pencangkulan dan pemerataan) mengikuti garis kontur sehingga terbentuk alur-alur dan jalur tumpukan tanah yang searah kontur dan memotong lereng. Alur-alur ini akan menghambat aliran air di permukaan dan mencegah erosi sehingga dapat menunjang konservasi di daerah tersebut.

4. Pelaksanaan slope reshaping, pembuatan bronjong kawat dan 
webbing jute juga dapat dilakukan agar lereng terjal tidak mudah terjadi erosi.

Perlunya penelitian lebih lanjut tentang parameter lainnya yang dapat mempengaruhi terjadinya longsor secara lengkap dan pelaksanaan mitigasi secara nyata di daerah Kecamatan Patuk.

\section{DAFTAR PUSTAKA}

Arsjad,A.B. Suriadi M. 2012. Informasi Geospasial Daerah Rawan Longsor Sebagai Bahan Masukan Dalam Perencanaan Tata Ruang Wilayah. Cibinong : Globe Volume 14 No.1 Juni 2012 : 37-45.

Arsjad, A.B. Suriadi M dan Riadi, Bambang. 2013. Potensi Risiko Bencana Alam Longsor Terkait Cuaca Ekstrim di Kabupaten Ciamis, Jawa Barat. Cibinong : Jurnal Ilmiah Geomatika Volume 19 No.1 Agustus 2013 : 57-63.

Badan Pusat Statistik (BPS) Kabupaten Gunungkidul. 2013. Gunung Kidul Dalam Angka (Gunungkidul in Figure) 2013. Gunungkidul : Badan Pusat Statistik Kabupaten Gunungkidul.

Badan Pusat Statistik (BPS) Kabupaten Gunungkidul. 2015. Gunung Kidul Dalam Angka (Gunungkidul in Figure) 2015.
Gunungkidul : Badan Pusat Statistik Kabupaten Gunungkidul.

BBSDLP (Balai Besar Litbang Sumberdaya Lahan Pertanian). 2009. Identifikasi dan Karakterisasi Lahan Rawan Longsor dan Rawan Erosi di Dataran Tinggi untuk Mendukung Keberlanjutan Pengelolaan Sumberdaya Lahan Pertanian. Bogor : Balai Besar Litbang Sumberdaya Lahan Pertanian.

Dariah, Ai., Haryati, Umi. dan Budhyastoro, Torry. 2009. Teknologi Konservasi Tanah Mekanik. Bogor : Teknik konservasi tanah 103-123.

Hartoyo, G.Manjella Eko., Nugroho, Yuli., Bhirowo, Ario. Dan Khalil, Bilaludin. 2010. Modul Pelatihan Sistem Informasi Geografis (SIG) Tingkat Dasar. Balikpapan : Tropenbos International Indonesia Programme.

Highland, Lynn.M dan Bobrowsky. 2008. The Landslide HandbookA Guide to Understanding landslides. Virginia : U.S. Geological Survey.

Lo, C.P. 1995. Penginderaan Jauh Terapan Terjemahan. Jakarta : Universitas Indonesia.

Nandi. 2007. Longsor. Bandung : FPIPS-UPI. 
Nasiah dan Invanni, Ichsan. 2014. Identifikasi Daerah Rawan Bencana Longsor Lahan Sebagai Upaya Penanggulangan Bencana di Kabupaten Sinjai. Makassar : Jurnal Sainsmat, ISSN 2086-6755, Halaman 109121.

Noorwantoro,

Muhammad.,

Asmaranto, Runi. dan

Harisuseno, Donny. 2014. Analisa Kawasan Rawan Bencana Tanah Longsor di DAS Upper Brantas Menggunakan Sistem Informasi Geografi. Malang : Jurusan Teknik Pengairan Fakultas Teknik, Universitas Brawijaya.

Paimin., Sukresno. dan Pramono, Irfan Budi. 2009. Teknik Mitigasi Banjir dan Tanah Longsor. Balikpapan : Tropenbos International Indonesia Programme ISBN 978-9793145-46-4.

Prahasta, Eddy. 2009. Sistem Informasi Geografis : Konsepkonsep Dasar (Perspektif Geodesi dan Geomatika). Bandung : Informatika.

Rahayu, Theresia Emi. 2012. Konsep Perencanaan dan Perancangan Hotel Resort di Bukit Patuk Gunungkidul yang Mengangkat
Kearifan Lokal. Surakarta : Jurusan Arsitektur Fakultas Teknik Universitas Sebelas Maret.

Rahmat AH. 2010. Pemetaan Kawasan Rawan Bencana dan Analisis Resiko Bencana Tanah Longsor dengan Sistem Informasi Geografis (SIG) (Studi Kasus Kawasan Kaki Gunung Ciremai, Kabupaten Majalengka) [Skripsi]. Bogor: Departemen Konservasi Sumberdaya Hutan dan Ekowisata Fakultas Kehutanan Institut Pertanian Bogor.

Rendra, Pradnya P. Raditya., Sulaksana, Nana. dan Alam, Boy Yoseph. 2016. Optimalisasi Pemanfaatan Sistem Agroforestri Sebagai Bentuk Adaptasi dan Mitigasi Tanah Longsor. Sumedang : Bulletin of Scientific Contribution, Volume 14, No.2 p-ISSN : 1693-4873.

Subardja S, Djaja., Ritung, Sofyan., Anda, Markus., Sukarman., Suryani, erna., Subandiono, Rudi. 2014. Petunjuk Teknis Klasifikasi Tanah Nasional. Jakarta : Badan Penelitian dan Pengembangan Pertanian Kementerian Pertanian (Agro Inovasi 